\title{
New treatment options for chronic constipation: Mechanisms, efficacy and safety
}

\author{
Michael Camilleri MD
}

M Camilleri. New treatment options for chronic constipation: Mechanisms, efficacy and safety. Can J Gastroenterol 2011;(Suppl B):29B-35B.

The present review has several objectives, the first of which is to review the pharmacology and selectivity of serotonergic agents to contrast the older serotonergic agents (which were withdrawn because of cardiac or vascular adverse effects) with the newer generation serotonin receptor subtype 4 agonists. Second, the chloride ion secretagogues that act through the guanylate cyclase $\mathrm{C}$ receptor are appraised and their pharmacology is compared with the approved medication, lubiprostone. Third, the efficacy and safety of the application of bile acid modulation to treat constipation are addressed. The long-term studies of surgically induced excess bile acid delivery to the colon are reviewed to ascertain the safety of this therapeutic approach. Finally, the new drugs for opiate-induced constipation are introduced. Assuming these drugs are approved, practitioners will have a choice; however, patient responsiveness will be based on trial and error. Nevertheless, the spectrum of mechanisms and demonstrated efficacy and safety augur well for satisfactory treatment outcomes.

Key Words: Opiate; Prokinetics; Secretagogues

A fter the exclusion of organic mucosal disease, strictures and evacuation disorders, the treatment of constipation is typically based on single or combined treatments with fibre $(1,2)$, osmotic laxatives (3) and stimulant laxatives (4) - to which many patients respond. The present article addresses newer classes of agents to treat constipation: new-generation serotonergic agents, chloride ion secretagogues acting through the guanylate cyclase $\mathrm{C}$ receptor and bile acid modulators. In view of increasingly encountered opiate-induced constipation, the new drugs being tested for this indication are also introduced.

\section{SEROTONIN, RECEPTORS AND OLDER SEROTONERGIC AGENTS}

Serotonin (5-hydroxytryptamine [5-HT]) is a ubiquitous molecule in the brain-gut axis, with $95 \%$ being present in the enteroendocrine cells of the gastrointestinal (GI) mucosa and, to a lesser extent, in interneurons within the gut plexuses. 5-HT is involved in GI secretion, sensation and motility (5). There are seven 5-HT receptor subtypes (6) and, through the different receptor subtypes, 5-HT induces diverse, sometimes opposite effects depending on the receptors stimulated or the activation of the same class of receptor on different types of enteric neurons activated in different sites in the gut (7), such as contraction in the gastric antrum through cholinergic neurons to accelerate gastric emptying (8) and relaxation in the gastric fundus through nitrergic neurons (9). The roles of 5-HT receptor subtype 3 $\left(5-\mathrm{HT}_{3}\right)$ and $5-\mathrm{HT}_{4}$ in GI motility have been the most extensively studied; $5-\mathrm{HT}_{4}$ receptors are abundantly present in the gut (10). Tegaserod, a $5-\mathrm{HT}_{4}$ receptor partial agonist, accelerated small bowel and colonic transit (11) and was efficacious in patients with functional constipation (12) and constipation-predominant irritable bowel syndrome (IBS-C) (13). However, the older generation $5-\mathrm{HT}_{4}$ agonists

\author{
De nouvelles options thérapeutiques contre la \\ constipation chronique : leurs mécanismes, leur \\ efficacité et leur innocuité
}

La présente analyse comporte plusieurs objectifs, le premier étant de réviser la pharmacologie et la sélectivité des sérotoninergiques pour comparer les anciens sérotoninergiques (retirés du marché en raison de leurs effets cardiaques ou vasculaires) avec les agonistes de récepteurs de la sérotonine de sous-type 4 de nouvelle génération. En deuxième lieu, les sécrétagogues des ions chlorures qui agissent par le récepteur du guanylatecyclase C sont évalués, et leur pharmacologie est comparée avec celle du lubiprostone, un médicament approuvé. En troisième lieu, l'efficacité et l'innocuité de l'application de la modulation de l'acide biliaire pour traiter la constipation sont abordées. Les études à long terme sur la livraison excessive d'acide biliaire dans le côlon, induite par la chirurgie, sont analysées afin d'évaluer l'innocuité de cette démarche thérapeutique. Enfin, les nouveaux médicaments contre la constipation induite par les opiacés sont présentés. Si ces médicaments sont approuvés, les praticiens auront un choix, mais la réponse des patients dépendra d'essais-erreurs. Néanmoins, le spectre des mécanismes et l'efficacité et l'innocuité démontrées augurent bien pour l'issue des traitements.

had relatively poor receptor selectivity, which led to rare side effects attributable to effects on other receptors or channels and impacted their risk-benefit profile.

Some $5-\mathrm{HT}_{4}$ agonists, such as cisapride, may cause ventricular arrhythmias. Cisapride blocks the hERG $\mathrm{K}^{+}$channel (IKr), thereby prolonging the repolarization phase of the ventricular action potential and the QT interval. The relative affinities of cisapride, tegaserod and of the new generation $5-\mathrm{HT}_{4}$ agonist, prucalopride, for $\mathrm{IKr}$ or for the $5-\mathrm{HT}_{4}$ receptor illustrates why cisapride is more likely than tegaserod and prucalopride to cause cardiac arrhythmias (14) (Figures $1 \mathrm{~A}, \mathrm{~B}$ and $\mathrm{C}$ ).

The tissue concentration of cisapride is increased in overdosing (eg, in pediatric patients), renal failure (lack of excretion), aging (altered pharmacokinetics) or drug interactions that inhibit hepatic CYP 3A4 metabolism, and the therapeutic window between desired GI versus cardiac adverse effects is narrowed further. Cardiac arrhythmia is unrelated to pharmacological activity at the $5-\mathrm{HT}_{4}$ receptor itself (15).

The 5-HT receptors $5-\mathrm{HT}_{1 \mathrm{~B}}, 5-\mathrm{HT}_{2 \mathrm{~A}}, 5-\mathrm{HT}_{2 \mathrm{~B}}, 5-\mathrm{HT}_{4}$ and $5-\mathrm{HT}_{7}$ are located on vascular smooth muscle cells and endothelial cells (16), and are involved in cardiovascular regulation. $5-\mathrm{HT}_{1 \mathrm{~B}}$ agonists induce contraction of arterioles and venules and constrict human coronary arteries (17). $5-\mathrm{HT}_{2 \mathrm{~B}}$ receptors may mediate vasodilation (18), and $5-\mathrm{HT}_{1 \mathrm{D}}, 5-\mathrm{HT}_{4}$ and $5-\mathrm{HT}_{7}$ receptors induce relaxation of venules.

Tegaserod was withdrawn from the market after an analysis found that 13 of 11,614 treated patients experienced ischemic cardiovascular events compared with one of 7031 patients given placebo (19). It is currently believed that lack of selectivity of tegaserod for $5-\mathrm{HT}_{4}$ receptors $(20)$ and its affinity for $5-\mathrm{HT}_{1 \mathrm{~B}}$ and $5-\mathrm{HT}_{2 \mathrm{~A}}$ receptors may have resulted in the cardiovascular risk.

Clinical Enteric Neuroscience Translational and Epidemiological Research (C.E.N.T.E.R.), College of Medicine, Mayo Clinic, Rochester, Minnesota, USA

Correspondence: Dr Michael Camilleri, Mayo Clinic, Charlton 8-110, 200 First Street Southwest, Rochester, Minnesota 55905, USA.

Telephone 507-266-2305, e-mail camilleri.michael@mayo.edu

Received for publication April 8, 2011, Accepted June 10, 2011 

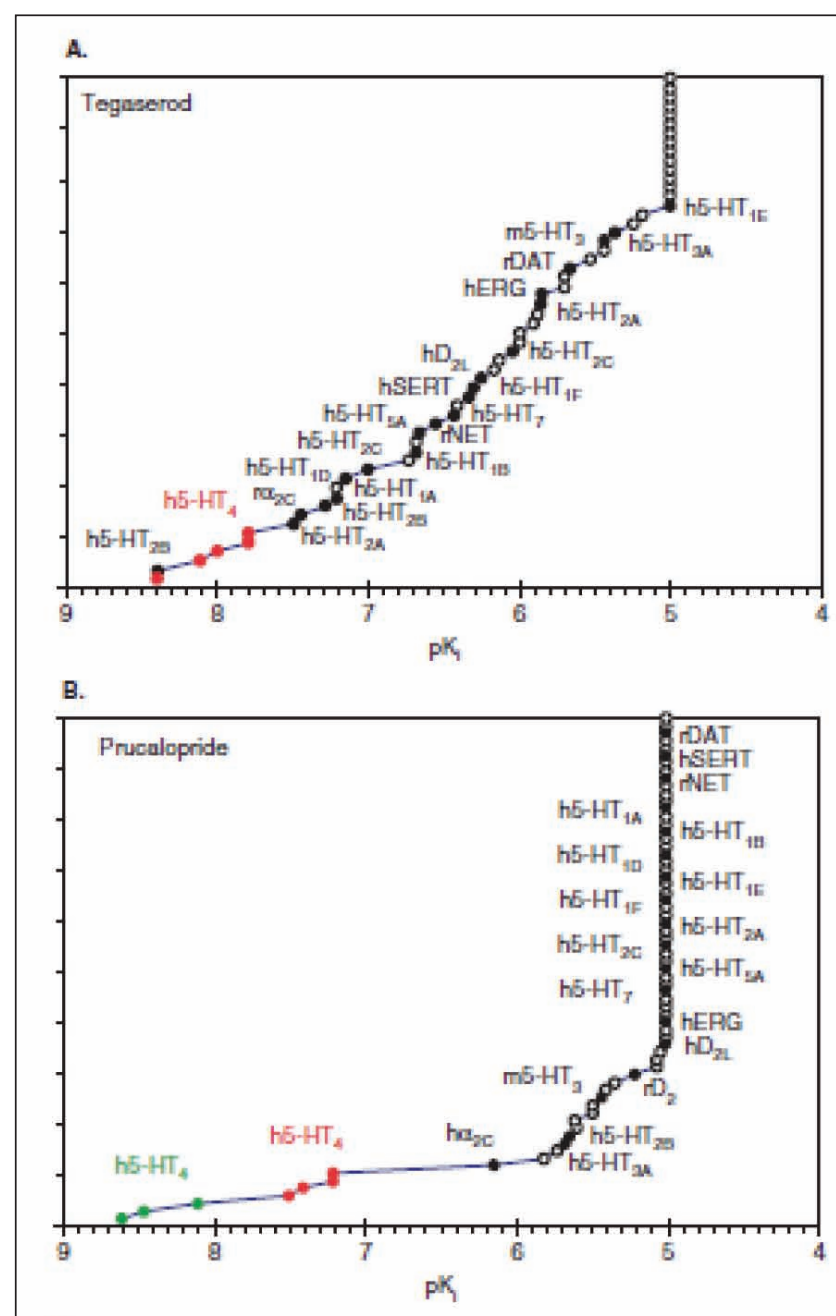

c.

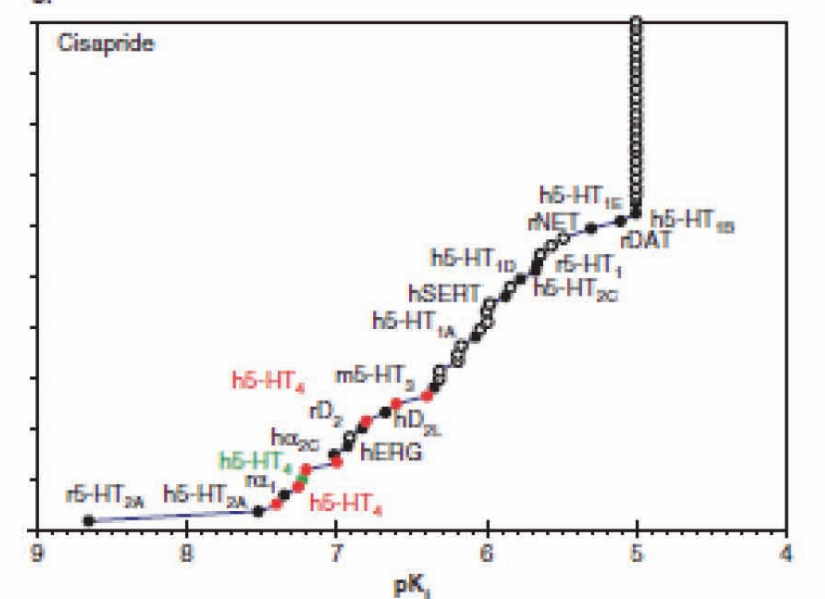

Figure 1) Selectivity of the human serotonin (h5-HT) receptor subtype 4 (5- $\mathrm{HT}_{4}$ ) agonists tegaserod (A), prucalopride (B) and cisapride (C). Note the lack of selectivity for the $h E R G$ channel of cisapride relative to tegaserod and prucalopride. $h$ Human; D dopamine; rDAT Rat dopamine transporter; hERG Human ether-a-go-go related gene; hNET Human norepinephrine transporter; hSERT Human serotonin transporter. Reproduced with permission from reference 14

\section{NEW TREATMENT OPTIONS FOR CONSTIPATION} NOT ASSOCIATED WITH EVACUATION DISORDERS Inexpensive treatments, such as fibre, osmotic and stimulant laxatives, that are available over the counter in many countries should be tried first - after exclusion of an evacuation disorder - in primary care settings and in gastroenterology clinics. Voderholzer et al (1) showed that patients who do not respond to these therapies may have constipation due to an evacuation disorder, slow-transit constipation or medication. Lubiprostone is an intestinal secretagogue that has been approved for chronic constipation (CC) and constipationpredominant IBS (IBS-C).

There are three general categories of medications that are being developed for the treatment of chronic idiopathic constipation: colonic prokinetics in the $5-\mathrm{HT}_{4}$ agonist class, intestinal secretagogues and bile acid modulators. In addition, there are more specific medications being developed for opioid-induced constipation (OIC).

\section{5- $\mathrm{HT}_{4}$ agonists}

The $5-\mathrm{HT}_{3}$ and $5-\mathrm{HT}_{4}$ receptors have been the most extensively studied targets of prokinetics in humans. They induce fast excitatory postsynaptic potentials in intrinsic neurons, release neurotransmitters such as acetylcholine, and induce mucosal secretion by activating submucosal neurons. Table 1 summarizes the three main candidate 5-HT $\mathrm{HT}_{4}$ agonists in development: prucalopride, velusetrag and naronapride (21). Their specificity and cardiovascular safety differ from those of the older $5-\mathrm{HT}_{4}$ agonists $(14,22)$.

The newer $5-\mathrm{HT}_{4}$ agonists exhibit high intrinsic activity and selectivity at intestinal $5-\mathrm{HT}_{4}$ receptors, and facilitate cholinergically mediated contractions; however, they have low intrinsic activity in other tissues, including cardiac muscle, thus achieving the desirable selectivity of action and probable cardiovascular safety.

There is considerable evidence supporting prucalopride's pharmacodynamic $(23,24)$ and clinical trial efficacy in patients with CC $(25-27)$, and it is safe in elderly patients (28). Doses of $2 \mathrm{mg}$ per day in adults and $1 \mathrm{mg}$ per day in elderly patients were approved for CC by the European Agency for Evaluation of Medicinal Products.

In vitro, velusetrag is a specific $5-\mathrm{HT}_{4}$ agonist (29) and has been shown to be safe and efficacious in vivo in animals (30), in pharmacodynamic studies in humans (31) and in a large (400 patient) phase-IIB study (32). Velusetrag has one metabolite that is almost as potent as the parent drug.

Naronapride also shows pharmacodynamic efficacy in animals and humans $(33,34)$. Although chemically related to cisapride, it does not undergo CYP3A4 metabolism and should, therefore, avoid the drug interactions that contributed to arrhythmias with cisapride.

\section{Intestinal chloride secretagogues}

These secretagogues increase intestinal chloride secretion with associated secretion of water into the lumen. There are several different classes of chloride channels (ClC), including $\mathrm{ClC}-2$ and $\mathrm{ClC}-3$, which are expressed in most cells. The chloride ions that are secreted from enterocytes or colonocytes enter the cell through the basolateral $\mathrm{Na}^{+}-\mathrm{K}^{+}-2 \mathrm{Cl}^{-}$cotransporter. The cations $\mathrm{Na}^{+}$and $\mathrm{K}^{+}$are then exported through the $\mathrm{Na}^{+}$pump (ie, $\mathrm{Na}^{+} / \mathrm{K}^{+}$-ATPase) and $\mathrm{KCNQ1/}$ $\mathrm{KCNE} 3$ heteromeric $\mathrm{K}^{+}$channels. Chloride secretory pathways in the apical membrane of epithelial cells include the cystic fibrosis transmembrane regulator (CFTR) and ClC-2 chloride channels (35).

Lubiprostone is a bicyclic fatty acid derived from prostaglandin E1. It activates apical membrane CIC-2 channels (36) and CFTR (37) to stimulate intestinal and colonic secretion of chloride-rich fluid into the intestinal lumen. Lubiprostone may also activate prostaglandin EP receptors (38).

Lubiprostone accelerated intestinal and colonic transit in healthy subjects (39) without significantly impacting colonic motility or sensation as measured by intraluminal probes in humans (40). Lubiprostone does not stimulate uterine smooth muscle in vitro (41), and it inhibits neuronally mediated contractions of colon circular muscle (38). Clinical trials have demonstrated that lubiprostone is efficacious and safe in patients with CC, and is marketed at a dose of $24 \mu \mathrm{g}$ twice daily for this indication $(42,43)$. Lubiprostone is reported to cause nausea in approximately $20 \%$ of patients.

Linaclotide and plecanatide activate secretion of chloride through guanylcyclase C (GC-C). GC-C is enriched in intestinal epithelium, 
TABLE 1

Comparison of novel serotonin $(5-\mathrm{HT})$ receptor subtype $4\left(5-\mathrm{HT}_{4}\right)$ agonists

\begin{tabular}{ll}
\hline Characteristic & Prucalopride \\
\hline Chemistry & Benzofuran carboxamide \\
Selectivity and affinity for & Highly selective, high affinity; weak affinity for human D4 \\
$5-\mathrm{HT}_{4}$ receptor & $\begin{array}{l}\text { and } \sigma 1, \text { and mouse } 5-\mathrm{HT}_{3} \text { receptors at concentrations } \\
\text { exceeding the } \mathrm{K}_{\mathrm{i}} \text { for } 5-\mathrm{HT}_{4} \text { receptors by 290-fold }\end{array}$
\end{tabular}

Metabolism

Limited hepatic, not CYP 3 A4

Pharmacodynamic efficacy Accelerated colonic transit in health and chronic in humans constipation

Clinical trial efficacy

Phase II and III portfolio in chronic constipation

Velusetrag

Quinolinone-carboxamide

Naronapride

High affinity and selectivity for $\mathrm{h} 5-\mathrm{HT}_{4 \mathrm{c}}$ over other biogenic amine receptors $>500$-fold selective over other $5-\mathrm{HT}$ receptors (including $\mathrm{h} 5-\mathrm{HT}_{2 \mathrm{~B}}, \mathrm{~h} 5-\mathrm{HT}_{3 \mathrm{~A}}$ ) CYP $3 A 4$

Accelerated colonic transit in health in dose-related fashion

Phase IIB

Benzamide

Open-label effectiveness

Arrhythmogenicity

Open-label experience of $\sim 1000$ cumulative patient-years -

No arrhythmic activity in human atrial cells; inhibited hERG At $3 \mu \mathrm{M}$, no effect on hERG channel channel only at $\mu \mathrm{M}$ concentration $\left(\mathrm{IC}_{50} \sim 4.9 \times 10^{-6} \mathrm{M}\right)$; no clinically relevant cardiac adverse events in clinical trials of $>4000$ human subjects

current; safety ratio versus cisapride >1000-fold; no effect on QT in health or 400 patients with constipation

Specific 5-HT4 full agonist activity in the GI tract, but a partial agonist activity in the heart

Hydrolytic esterase, not CYP 3 A4

Accelerated colonic transit in health

Phase IB

$-$

At $100 \mu \mathrm{M}$, no effect on hERG channel; affinity ratio between $\mathrm{I}_{\mathrm{Kr}}$ and $5-\mathrm{HT}_{4}$ receptors of $>1000$ fold Healthy subjects "thorough" QTc study; safety in elderly cohort $80 \%$ on cardiovascular drugs

Healthy subjects "thorough" QTc study; transient increase in heart rate not different from placebo Healthy subjects "thorough" QTc study including elderly

Diarrhea, headache

Diarrhea, nausea, headache

Diarrhea, headache

Most common adverse

events

Approval status

EMEA

Data from reference 21. EMEA European Agency for Evaluation of Medicinal Products; GI Gastrointestinal; $h$ Human; $h E R G$ Human ether-a-go-go related gene; IC Inhibitory concentration; $I_{K r}$ delayed rectifier $K^{+}$channel; QTC Corrected QT interval

\section{TABLE 2}

Comparison of the secretagogues lubiprostone and linaclotide

\begin{tabular}{|c|c|c|}
\hline Characteristic & Lubiprostone & Linaclotide \\
\hline Chemistry & Bicyclic fatty acid called a prostone & 14 amino acid peptide, analogue of guanylin \\
\hline Target receptor & Chloride channel (CIC2); ? CFTR involved & Guanylate cyclase C receptor activation with CFTR-mediated secretion \\
\hline Pharmacodynamics in humans & Accelerated small bowel and colonic transit in health & $\begin{array}{l}\text { Accelerated colonic transit in constipation-predominant irritable } \\
\text { bowel syndrome in dose-related fashion }\end{array}$ \\
\hline Clinical trial efficacy & $\begin{array}{l}\text { Phase II and III portfolio in chronic constipation and } \\
\text { constipation-predominant irritable bowel syndrome }\end{array}$ & $\begin{array}{l}\text { Phase IIB in chronic constipation and constipation-predominant } \\
\text { irritable bowel syndrome }\end{array}$ \\
\hline Open-label effectiveness & Clinical practice experience & - \\
\hline Arrhythmogenicity & No arrhythmic activity & Low bioavailability no arrhythmic activity \\
\hline Cardiovascular safety & Healthy subjects "thorough" QTc study & Healthy subjects "thorough" QTc study \\
\hline Most common adverse events & Diarrhea, nausea & Diarrhea \\
\hline Potential other actions & Mucosal protection & Antineoplastic \\
\hline Approval status & United States Food and Drug Administration & - \\
\hline
\end{tabular}

Data from reference 21. CFTR Cystic fibrosis transmembrane conductance regulator; QTC Corrected QT interval

although it is detected in other epithelia. It is the receptor responsible for heat-stable enterotoxin (STa) Escherichia coli diarrhea; these enteric bacterial peptides are 19 amino acids (AAs) in length (44). There are two endogenous ligands of GC-C: the small cysteine-rich peptides, guanylin (15 AA) and uroguanylin (16 AA). These peptides are released in an autocrine or paracrine fashion into the intestinal lumen; they also function as endocrine hormones regulating ion transport in extraintestinal epithelia (eg, kidney).

In the intestine, activation of GC-C results in the stimulation of chloride and bicarbonate secretion through the opening of apical CFTR chloride channels and inhibition of sodium absorption through blockade of an apical $\mathrm{Na}^{+} / \mathrm{H}^{+}$exchanger. The principal effector of the GC-C effect on ion transport is cyclic GMP-dependent protein kinase type II.

Linaclotide is a 14 AA peptide that contains three disulfide bonds required for GC-C activation. The active metabolite, MM-419447, is produced after loss of the C-terminal tyrosine through the action of carboxypeptidase A. By increasing cyclic GMP levels, linaclotide stimulates chloride and bicarbonate secretion through CFTR channeldependent and, to a lesser extent, channel-independent mechanisms (45). Linaclotide also inhibits sodium absorption from the lumen via a sodium proton exchanger (46). Linaclotide accelerated colonic transit (47), enhanced intestinal secretion (48) and improved symptoms in patients with CC $(49,50)$.

Plecanatide (SP-304) is a synthetic analogue of uroguanylin in development for IBS-C and CC. It was tested in early studies (51) to characterize its safety and pharmacokinetics, and to obtain early efficacy demonstrated by altered stool consistency. In addition, it improved symptoms of constipation such as frequency, consistency, straining and abdominal discomfort in 80 patients with $\mathrm{CC}$ in the first phase-IIA 14-day treatment study of daily doses of $0.3 \mathrm{mg}, 1 \mathrm{mg}$, $3 \mathrm{mg}$ and $9 \mathrm{mg}$ (52). (21).

Table 2 summarizes the properties of lubiprostone and linaclotide

Bile acid modulation

Under physiological conditions, approximately $95 \%$ of bile acids secreted into the duodenum are actively reabsorbed in the terminal ileum. Inadequate reabsorption and delivery of bile acids into the colon result in secretory diarrhea (53), chiefly by increasing permeability (54) or by activating adenylate cyclase (55). Both conjugated and nonconjugated bile acids induce secretion in the human colon 
TABLE 3

Pharmacological approaches to treat opiate-induced constipation (OIC)

\begin{tabular}{|c|c|c|c|c|}
\hline Drug name & Drug class & Pharmacodynamic efficacy in humans & Clinical trial optimal efficacy and safety & Ref(s) \\
\hline Naloxone & $\begin{array}{l}\text { Nonselective opioid } \\
\text { antagonist }\end{array}$ & $\begin{array}{l}\text { Reverses opiate-induced delay in orocecal and } \\
\text { colonic transit }\end{array}$ & $\begin{array}{l}\text { Naloxone PR formulation prevents OIC in patients receiving } \\
\text { PR oxycodone }\end{array}$ & $72-77$ \\
\hline $\begin{array}{l}\text { Methyl } \\
\text { naltrexone } \\
\text { (MNTX) }\end{array}$ & M-opioid antagonist & $\begin{array}{l}\text { Reverses effects of opiate in health and of } \\
\text { chronic methadone treatment on orocecal } \\
\text { transit; no effect on small intestinal or colonic } \\
\text { transit delayed by codeine } 30 \mathrm{mg} \text { qid in } \\
\text { opiate-naive healthy subjects }\end{array}$ & $\begin{array}{l}\text { Subcutaneous MNTX } 0.15 \mathrm{mg} / \mathrm{kg} \text { on alternate days effective in } \\
\text { inducing laxation in patients with advanced illness }\end{array}$ & $78-85$ \\
\hline $\begin{array}{l}\text { Naltrexone } \\
\text { ER }\end{array}$ & $\begin{array}{l}\text { M-opioid antagonist as } \\
\text { sequestered core: } \\
\text { ratio naltrexone to } \\
\text { morphine } 4 \%\end{array}$ & ND & $\begin{array}{l}\text { Open-label } 12 \text {-month safety of combination extended-release } \\
\text { pellets of morphine (median } 59 \mathrm{mg} / \text { day) with a sequestered } \\
\text { naltrexone core (qd or bid): OIC 31.8\%, nausea } 25.2 \% \text {; opiate } \\
\text { withdrawal }<5 \%\end{array}$ & 86 \\
\hline Alvimopan & PAMORA & $\begin{array}{l}8 \mathrm{mg} \text { oral dose accelerates colonic transit and } \\
\text { reverse effects of codeine in opiate-naive } \\
\text { healthy volunteers receiving codeine } 30 \mathrm{mg} \text { qid }\end{array}$ & $\begin{array}{l}0.5 \mathrm{mg} \text { bid dose efficacious in treating OIC; rare instances of } \\
\text { ischemic heart disease }\end{array}$ & 87,88 \\
\hline NKTR-118 & $\begin{array}{l}\text { PAMORA; PEGylated } \\
\text { naloxol conjugate }\end{array}$ & $\begin{array}{l}\text { Normalized morphine-induced delay in orocecal } \\
\text { transit }\end{array}$ & $\begin{array}{l}25 \mathrm{mg} \text { and } 50 \mathrm{mg} \text { NKTR-118 had increased number of SBM } \\
\text { during the first week and overall } 4 \text { weeks of treatment of OIC } \\
\text { patients }\end{array}$ & 89,90 \\
\hline TD-1211 & PAMORA & ND & $\begin{array}{l}5 \text { mg/day and } 10 \text { mg/day TD-1211 increased average } \\
\text { SBM/week over } 2 \text { weeks in OIC patients }\end{array}$ & 91 \\
\hline Tapentadol & $\begin{array}{l}\text { M-opioid agonist plus } \\
\text { norepinephrine } \\
\text { reuptake inhibitor }\end{array}$ & ND & $\begin{array}{l}\text { Tapentadol ER 100-250 mg bid equally effective for moderate } \\
\text { to severe chronic osteoarthritis-related knee pain or chronic } \\
\text { low back pain compared with oxycodone } \mathrm{HCl}(\mathrm{CR}) 20 \mathrm{mg} \text { to } \\
50 \mathrm{mg} \text { bid daily with less bowel dysfunction symptoms }\end{array}$ & $92-94$ \\
\hline
\end{tabular}

bid Twice per day; CR Controlled release; ER Extended release; ND Not done; PAMORA Peripherally restricted $\mu$ (M)-opioid receptor antagonist; PEG Polyethylene glycol; PR Prolonged release; qd Once per day; qid Four times per day; SBM Spontaneous bowel movements. Data from reference (Ref) 71

$(56,57)$; hence, the delivery of any excess bile acids to the colon can result in secretion. Bile acids also increase colonic motility $(58,59)$, although the most effective dose is unclear. Ileocolonic delivery of sodium chenodeoxycholate (CDC) results in accelerated colonic transit, increased stool frequency and consistency in healthy volunteers, and in patients with IBS-C $(60,61)$ at relatively low doses of $0.5 \mathrm{~g} /$ day to $1.0 \mathrm{~g}$ /day, whereas higher doses $(2.25 \mathrm{~g} /$ day $)$ of oral CDC were of variable efficacy in patients with CC (62).

A novel approach to deliver bile acids to the colon to treat CC involves the inhibition of the ileal bile acid transporter (IBAT, also known as the apical sodium-dependent bile acid transporter). A3309 is a selective inhibitor of the IBAT and has been shown to reduce meat-induced constipation in dogs (63). In humans, A3309 enhanced colonic transit in a multiple ascending dose, phase-IB study in patients with chronic idiopathic constipation (64). In a single-centre, pharmacodynamic, placebo-controlled study of $15 \mathrm{mg}$ and $20 \mathrm{mg}$ doses of A3309, Wong et al (65) demonstrated that A3309 accelerated colonic transit at $24 \mathrm{~h}$ and $48 \mathrm{~h}$, and had significant effects on stool consistency, constipation rating, ease of stool passage and reduction of straining. Treatment was associated with increased serum levels of $7 \alpha$-hydroxy-4-cholesten-3-one, consistent with stimulation of hepatocyte bile acid synthesis as a result of inhibition of ileal bile acid absorption.

In a randomized, placebo-controlled, eight-week, multicentre, parallel-group, phase-IIB trial of 190 patients, Chey et al (66) evaluated the effects of a one-week treatment with $5 \mathrm{mg}, 10 \mathrm{mg}$ and $15 \mathrm{mg}$ of A3309 (66), and observed that the $10 \mathrm{mg}$ and $15 \mathrm{mg}$ doses significantly increased stool frequency and improved constipation-related symptoms during the first week. The beneficial effects were maintained over the eight-week treatment period.

Malabsorbed bile acids have the potential to induce neoplastic transformation in the colonic epithelium if the latter is also exposed to a carcinogen in an experimental model (67). The data from long-term follow-up studies of patients after partial ileal bypass performed for hyperlipidemia (68) are reassuring. There was no increased prevalence of colorectal cancer at five years follow-up $(1.9 \%$ colorectal cancers in the control group and $2.4 \%$ in the surgery group; $\mathrm{P}=0.69$ ). A 25 -year, long-term follow-up study did not reveal any differences in cancer rate (11\% in the control group and $9 \%$ in the surgery group [69]). In a recent review, Bajor et al (70) concluded that there is no firm evidence that clinically relevant concentrations of bile acids induce colon cancer.

\section{NEW APPROACHES TO TREAT OIC}

OIC is experienced by approximately $40 \%$ of patients who receive chronic treatment with opioids for chronic noncancer pain. The experience of constipation and other GI symptoms may dissuade patients from using the required analgesic dose to achieve effective pain relief. Opiates have several effects on GI function, and the inhibition of colonic transit and intestinal and colonic secretion result in constipation. Several different pharmacological approaches are being developed to prevent or treat OIC: prolonged-release formulations that contain naloxone (a less-specific opiate antagonist that is widely distributed); and a new class of peripherally-restricted $\mu$-opiate receptor antagonists including methyl naltrexone, alvimopan, tapentadol, NKTR-118 and TD-1211. These agents are summarized in Table 3 (71).

Because OIC is not the main focus of the current article, the individual trials are not discussed; they are, however, referenced in Table 3 (72-94). In addition, lubiprostone and prucalopride have been reported to relieve OIC $(95,96)$.

\section{CONCLUSION}

The novel therapeutic options for CC appear to be safe and efficacious, and activate diverse mechanisms to induce increased motility or secretion in both the small bowel and colon (eg, lubiprostone, linaclotide and plecanatide) or predominantly in the colon (eg, A3309). Current studies do not differentiate patients with abnormal secretion as the cause of constipation, normal or delayed colonic transit constipation. Thus, after these drugs are approved, practitioners will have a choice; however, patient responsiveness will be based on trial and error. Nevertheless, the spectrum of mechanisms, and demonstrated efficacy and safety augur well for satisfactory treatment outcomes. 
ACKNOWLEDGEMENTS: The author gratefully acknowledges the excellent secretarial support of Mrs Cindy Stanislav.

DISCLOSURES: Dr Camilleri has received research grants from Theravance, ARYx, Takeda-Sucampo, Microbia, Albireo, Adolor, and Wyeth to study pharmacodynamic effects of velusetrag, naronapride, lubiprostone, linaclotide, A3309, alvimopan, and methylnaltrexone, respectively. He also served on advisory boards for these companies and Synergy (regarding plecanatide) when he was not conducting research on the drugs. He received personal compensation that was below the federal threshold for significant conflict of interest for serving as an advisor.

\section{REFERENCES}

1. Voderholzer WA, Schatke W, Mühldorfer BE, Klauser AG, Birkner B, Müller-Lissner SA. Clinical response to dietary fiber treatment of chronic constipation. Am J Gastroenterol 1997;92:95-8.

2. Suares NC, Ford AC. Systematic review: The effects of fibre in the management of chronic idiopathic constipation. Aliment Pharmacol Ther 2011;33:895-901.

3. Dipalma JA, Cleveland MV, McGowan J, Herrera JL. A randomized, multicenter, placebo-controlled trial of polyethylene glycol laxative for chronic treatment of chronic constipation. Am J Gastroenterol 2007;102:1436-41.

4. Kienzle-Horn S, Vix JM, Schuijt C, Peil H, Jordan CC, Kamm MA. Efficacy and safety of bisacodyl in the acute treatment of constipation: A double-blind, randomized, placebo-controlled study. Aliment Pharmacol Ther 2006;23:1479-88.

5. Kim DY, Camilleri M. Serotonin: A mediator of the brain-gut connection. Am J Gastroenterol 2000;95:2698-709.

6. Hoyer D, Hannon JP, Martin GR. Molecular, pharmacological and functional diversity of 5-HT receptors. Pharmacol Biochem Behav 2002;71:533-54

7. Tonini M, Pace F. Drugs acting on serotonin receptors for the treatment of functional GI disorders. Dig Dis 2006;24:59-69.

8. Maddern GJ, Jamieson GG, Myers JC, Collins PJ. Effect of cisapride on delayed gastric emptying in gastro-oesophageal reflux disease. Gut 1991;32:470-4.

9. Tack J, Broeckaert D, Coulie B, Janssens J. The influence of cisapride on gastric tone and the perception of gastric distension. Aliment Pharmacol Ther 1998;12:761-6.

10. Hegde SS, Eglen RM. Peripheral 5-HT4 receptors. FASEB J 1996;10:1398-407.

11. Prather CM, Camilleri M, Zinsmeister AR, McKinzie S, Thomforde GM. Tegaserod accelerates orocecal transit in patients with constipation-predominant irritable bowel syndrome. Gastroenterology 2000;118:463-8.

12. Quigley EM, Wald A, Fidelholtz J, et al. Safety and tolerability of tegaserod in patients with chronic constipation: Pooled data from two phase III studies. Clin Gastroenterol Hepatol 2006;4:605-13.

13. Evans BW, Clark WK, Moore DJ, Whorwell PJ. Tegaserod for the treatment of irritable bowel syndrome. Cochrane Database Syst 2007;(4):CD003960.

14. Demaeyer JH, Lefebvre RA, Schuurkes JAJ. 5-HT4 receptor agonists: Similar but not the same. Neurogastroenterol Motil 2008;20:99-112.

15. Mohamand S, Zhou Z, Gong Q, January CT. Blockage of the HERG human cardiac $\mathrm{K}^{+}$channel by the gastrointestinal prokinetic agent cisapride. Am J Physiol 1997;273:H2534-8.

16. Nilsson T, Longmore J, Shaw D, et al. Characterization of 5-HT receptors in human coronary arteries by molecular and pharmacological techniques. Eur J Pharmacol 1999;372:49-56.

17. MaassenVanDenBrink, Reekers M, Bax WA, Saxena PR. Human isolated coronary artery contraction to sumatriptan characterized by the selective $5-\mathrm{HT} 1 \mathrm{~B} / 1 \mathrm{D}$ receptor antagonist GR55562. Pharmacol Toxicol 2000;86:287-90.

18. Villalón CM, Centurión D. Cardiovascular responses produced by 5-hydroxytriptamine: A pharmacological update on the receptors/ mechanisms involved and therapeutic implications. Naunyn Schmiedeberg's Arch 2007;376:45-63.

19. United States Food and Drug Administration. $<$ www.fda.gov/Drugs/DrugSafety/

PostmarketDrugSafetyInformationforPatientsandProviders/
DrugSafetyInformationforHeathcareProfessionals/

PublicHealthAdvisories/ucm051284.htm>

(Accessed on June 27, 2011).

20. Beattie DT, Smith JA, Marquess D, et al. The 5-HT4 receptor agonist, tegaserod, is a potent 5-HT2B receptor antagonist in vitro and in vivo. Br J Pharmacol 2004;143:549-60.

21. Camilleri M, Bharucha AE. Behavioural and new pharmacological treatments for constipation: Getting the balance right. Gut 2010;59:1288-96.

22. De Maeyer JH, Prins NH, Schuurkes JA, Lefebvre RA. Differential effects of 5-hydroxytryptamine4 receptor agonists at gastric versus cardiac receptors: An operational framework to explain and quantify organ-specific behavior. J Pharmacol Exp Ther 2006;317:955-64.

23. Bouras EP, Camilleri M, Burton DD, et al. Prucalopride accelerates gastrointestinal and colonic transit in patients with constipation without a rectal evacuation disorder. Gastroenterology 2001;120:354-60.

24. Sloots CE, Poen AC, Kerstens R, et al. Effects of prucalopride on colonic transit, anorectal function and bowel habits in patients with chronic constipation. Aliment Pharmacol Ther 2002;16:759-67.

25. Camilleri M, Kerstens R, Rykx A, Vandeplassche L. A placebo-controlled trial of prucalopride for severe chronic constipation. N Engl J Med 2008;358:2344-54.

26. Quigley EM, Vandeplassche L, Kerstens R, Ausma J. Clinical trial: The efficacy, impact on quality of life, and safety and tolerability of prucalopride in severe chronic constipation - a 12-week, randomized, double-blind, placebo-controlled study. Aliment Pharmacol Ther 2009;29:315-28.

27. Tack J, van Outryve M, Beyens G, et al. Prucalopride (Resolor) in the treatment of severe chronic constipation in patients dissatisfied with laxatives. Gut 2009;58:357-65.

28. Camilleri M, Beyens G, Kerstens R, Robinson P, Vandeplassche L. Safety assessment of prucalopride in elderly patients with constipation: A double-blind, placebo-controlled study. Neurogastroenterol Motil 2009;21:1256-63.

29. Smith JA, Beattie DT, Marquess D, Shaw JP, Vickery RG, Humphrey PP. The in vitro pharmacological profile of TD-5108, a selective $5-\mathrm{HT}(4)$ receptor agonist with high intrinsic activity. Naunyn Schmiedebergs Arch Pharmacol 2008;378:125-37.

30. Beattie DT, Armstrong SR, Shaw JP, et al. The in vivo gastrointestinal activity of TD-5108, a selective 5-HT(4) receptor agonist with high intrinsic activity. Naunyn Schmiedebergs Arch Pharmacol 2008;378:139-47.

31. Manini ML, Camilleri M, Goldberg M, et al. Effects of velusetrag (TD-5108) on gastrointestinal transit and bowel function in health and pharmacokinetics in health and constipation.

Neurogastroenterol Motil 2010;22:42-9.

32. Goldberg M, Li YP, Johanson JF, et al. Clinical trial: The efficacy and tolerability of velusetrag, a selective 5-HT4 agonist with high intrinsic activity, in chronic idiopathic constipation - a 4-week, randomized, double-blind, placebo-controlled, dose-response study. Aliment Pharmacol Ther 2010;32:1102-12.

33. Dennis D, Palme M, Irwin I, Druzgala P, Teichman S. ATI-7505 is a novel, selective $5 \mathrm{HT}(4)$ receptor agonist that causes gastrointestinal prokinetic activity in dogs. Gastroenterology 2004;126:A641.

34. Camilleri M, Vazquez-Roque MI, Burton D, et al. Pharmacodynamic effects of a novel prokinetic 5-HT receptor agonist, ATI-7505, in humans. Neurogastroenterol Motil 2007;19:30-8.

35. Barrett KE, Keely SJ. Chloride secretion by the intestinal epithelium: Molecular basis and regulatory aspects. Annu Rev Physiol 2000;62:535-72.

36. Cuppoletti J, Malinowska DH, Tewari KP, et al. SPI-0211 activates T84 cell chloride transport and recombinant human ClC-2 chloride currents. Am J Physiol 2004;287:C1173-83.

37. Bijvelds MJ, Bot AG, Escher JC, De Jonge HR. Activation of intestinal $\mathrm{Cl}^{-}$secretion by lubiprostone requires the cystic fibrosis transmembrane conductance regulator. Gastroenterology 2009;137:976-85.

38. Bassil AK, Borman RA, Jarvie EM, et al. Activation of prostaglandin EP receptors by lubiprostone in rat and human stomach and colon. Br J Pharmacol 2008;154:126-35.

39. Camilleri M, Bharucha AE, Ueno R, et al. Effect of a selective chloride channel activator, lubiprostone, on gastrointestinal transit, gastric sensory and motor functions in healthy volunteers. Am J Physiol 2006;290:G942-7. 
40. Sweetser S, Busciglio IA, Camilleri M, et al. Effect of a chloride channel activator, lubiprostone, on colonic sensory and motor functions in healthy subjects. Am J Physiol 2009;296:G295-301.

41. Cuppoletti J, Malinowska DH, Chakrabarti J, Ueno R. Effects of lubiprostone on human uterine smooth muscle cells. Prostaglandins Other Lipid Mediat 2008;86:56-60.

42. Johanson JF, Ueno R. Lubiprostone, a locally acting chloride channel activator, in adult patients with chronic constipation: A double-blind, placebo-controlled, dose-ranging study to evaluate efficacy and safety. Aliment Pharmacol Ther 2007;25:1351-61.

43. Johanson JF, Morton D, Geenen J, Ueno R. Multicenter, 4-week, double-blind, randomized, placebo-controlled trial of lubiprostone, a locally-acting type-2 chloride channel activator, in patients with chronic constipation. Am J Gastroenterol 2008;103:170-7.

44. Vaandrager AB. Structure and function of the heat-stable enterotoxin receptor guanylyl cyclase C. Mol Cell Biochem 2002;230:73-83.

45. Joo NS, London RM, Kim HD, Forte LR, Clarke LL. Regulation of intestinal $\mathrm{Cl}^{-}$and $\mathrm{HCO}_{3}{ }^{-}$secretion by uroguanylin. Am J Physiol 1998;274:G633-44.

46. Donowitz M, Cha B, Zachos NC, et al. NHERF family and NHE3 regulation. J Physiol 2005;567:3-11.

47. Andresen V, Camilleri M, Busciglio IA, et al. Effect of 5 days linaclotide on transit and bowel function in females with constipation-predominant irritable bowel syndrome. Gastroenterology 2007;133:761-8.

48. Busby RW, Bryant AP, Bartolini WP, et al. Linaclotide, through activation of guanylate cyclase $\mathrm{C}$, acts locally in the gastrointestinal tract to elicit enhanced intestinal secretion and transit. Eur J Pharmacol 2010;649:328-35.

49. Johnston JM, Kurtz CB, Drossman DA, et al. Pilot study on the effect of linaclotide in patients with chronic constipation. Am J Gastroenterol 2009;104:125-32.

50. Lembo AJ, Kurtz CB, Macdougall JE, et al. Efficacy of linaclotide for patients with chronic constipation. Gastroenterology 2010;138:886-95.

51. Shailubhai K, Gerson WA, Talluto C, Jacob GS. SP-304 to treat GI disorders - effects of a single, oral-dose of SP-304 on safety, tolerability, pharmacokinetics and pharmacodynamics in healthy volunteers. Gastroenterology 2009;136(Suppl 1):A641. (Abst)

52. Shailubhai K, Talluto C, Comiskey S, Foss JA, Joslyn A, Jacob G. Phase II clinical evaluation of SP-304, a guanylate cyclase-C agonist, for treatment of chronic constipation. Am J Gastroenterol 2010;105:S487-8.

53. Hofmann AF. The continuing importance of bile acids in liver and intestinal disease. Arch Intern Med 1999;159:2647-58.

54. Chadwick VS, Gaginella TS, Carlson GL, Debongnie JC, Phillips SF, Hofmann AF. Effect of molecular structure on bile acid-induced alterations in absorptive function, permeability, and morphology in the perfused rabbit colon. J Lab Clin Med 1979;94:661-74.

55. Conley DR, Coyne MJ, Bonorris GG, Chung A, Schoenfield LJ. Bile acid stimulation of colonic adenylate cyclase and secretion in the rabbit. Am J Dig Dis 1976;21:453-8.

56. Mekhjian HS, Phillips SF, Hofmann AF. Colonic secretion of water and electrolytes induced by bile acids: Perfusion studies in man. J Clin Invest 1971;50:1569-77.

57. Wingate DL, Phillips SF, Hofmann AF. Effect of glycine-conjugated bile acids with and without lecithin on water and glucose absorption in perfused human jejunum. J Clin Invest 1973;52:1230-6.

58. Kirwan WO, Smith AN, Mitchell WD, Falconer JD, Eastwood MA. Bile acids and colonic motility in the rabbit and the human. Gut 1975;16:894-902.

59. Bampton PA, Dinning PG, Kennedy ML, Lubowski DZ, Cook IJ. The proximal colonic motor response to rectal mechanical and chemical stimulation. Am J Physiol 2002;282:G443-9.

60. Odunsi ST, Camilleri M, McKinzie S, et al. Effects of chenodeoxycholate and a bile acid sequestrant, colesevelam, on intestinal transit and bowel function. Clin Gastroenterol Hepatol 2010;8:159-65.

61. Rao AS, Wong BS, Camilleri M, et al. Chenodeoxycholate in females with irritable bowel syndrome-constipation: A pharmacodynamic and pharmacogenetic analysis. Gastroenterology 2010;139:1549-58.

62. Bazzoli F, Malavolti M, Petronelli A, Barbara L, Roda E. Treatment of constipation with chenodeoxycholic acid. J Int Med Res 1983;11:120-3.
63. Gillberg, PG, Dahlström M, Starke I, et al. The IBAT inhibition by A3309 - a potential mechanism for the treatment of constipation. Gastroenterology 2010;5(Suppl 1):224.

64. Simren M, Abrahamsson H, Bajor A, et al. The IBAT inhibitor A3309 - a promising treatment option for patients with chronic idiopathic constipation. Gastroenterology 2010;5(Suppl 1):223.

65. Wong B, Camilleri M, McKinzie S, Burton D, Graffner H, Zinsmeister AR. Effects of A3309, an ileal bile acid transporter inhibitor, on colonic transit and symptoms in functional constipation. Gastroenterology 2011;140(Suppl 1):S146-7 .

66. Chey WD, Camilleri M, Chang L, Rikner L, Graffner H. A randomized placebo-controlled phase IIb trial of A3309, a bile acid transport inhibitor, for chronic idiopathic constipation. Am J Gastroenterol 2011 May 24 (E-pub ahead of print).

67. Morvay K, Szentleleki K, Torok G, Pinter A, Borzsonyi M, Nawroth R. Effect of change of fecal bile acid excretion achieved by operative procedures on 1,2-dimethylhydrazine-induced colon cancer in rats. Dis Colon Rectum 1989;32:860-3.

68. Buchwald H, Varco RL, Boen JR, et al. Effective lipid modification by partial ileal bypass reduced long-term coronary heart disease mortality and morbidity: Five-year post trial follow-up report from the POSCH: Program on the Surgical Control of the Hyperlipidemias. Arch Intern Med 1998;158:1253-61.

69. Buchwald H, Rudser KD, Williams SE, Michalek VN, Vagasky J, Connett JE. Overall mortality, incremental life expectancy, and cause of death at 25 years in the program on the surgical control of the hyperlipidemias. Ann Surg 2010;251:1034-40.

70. Bajor A, Gillberg PG, Abrahamsson H. Bile acids: Short and long term effects in the intestine. Scand J Gastroenterol 2010;45:645-64.

71. Camilleri M. Opioid-induced constipation: Challenges and therapeutic opportunities. Am J Gastroenterol 2011 Feb 22 (Epub ahead of print).

72. Basilisco G, Camboni G, Bozzani A, et al. Oral naloxone antagonizes loperamide-induced delay of orocecal transit. Dig Dis Sci 1987;32:829-32.

73. Kaufman PN, Krevsky B, Malmud LS, et al. Role of opiate receptors in the regulation of colonic transit. Gastroenterology 1988;94:1351-6.

74. Meissner W, Schmidt U, Hartmann M, et al. Oral naloxone reverses opioid-associated constipation. Pain 2000;84:105-9.

75. Vondrackova D, Leyendecker P, Meissner W, et al. Analgesic efficacy and safety of oxycodone in combination with naloxone as prolonged release tablets in patients with moderate to severe chronic pain. J Pain 2008;9:1144-54.

76. Meissner W, Leyendecker P, Mueller-Lissner S, et al. A randomised controlled trial with prolonged-release oral oxycodone and naloxone to prevent and reverse opioid-induced constipation. Eur J Pain 2009;13:56-64.

77. Sandner-Kiesling A, Leyendecker P, Hopp M, et al. Long-term efficacy and safety of combined prolonged-release oxycodone and naloxone in the management of non-cancer chronic pain. Int J Clin Pract 2010;64:763-74.

78. Yuan CS. Methylnaltrexone mechanisms of action and effects on opioid bowel dysfunction and other opioid adverse effects. Ann Pharmacother 2007;41:984-93.

79. Yuan CS, Foss JF, O'Connor M, et al. Methylnaltrexone for reversal of constipation due to chronic methadone use: A randomized controlled trial. JAMA 2000;283:367-72.

80. Yuan CS, Foss JF, Osinski J, et al. The safety and efficacy of oral methylnaltrexone in preventing morphine-induced delay in oral-cecal transit time. Clin Pharmacol Ther 1997;61:467-75.

81. Yuan CS, Foss JF, O'Connor M, et al. Methylnaltrexone prevents morphine-induced delay in oral-cecal transit time without affecting analgesia: A double-blind randomized placebo-controlled trial. Clin Pharmacol Ther 1996;59:469-75.

82. Yuan CS, Foss JF, O'Connor M, et al. Effects of intravenous methylnaltrexone on opioid-induced gut motility and transit time changes in subjects receiving chronic methadone therapy: A pilot study. Pain 1999;83:631-5.

83. Yuan CS, Foss JF, O'Connor M, et al. Effects of enteric-coated methylnaltrexone in preventing opioid-induced delay in oral-cecal transit time. Clin Pharmacol Ther 2000;67:398-404.

84. Thomas J, Karver S, Cooney GA, et al. Methylnaltrexone for opioid-induced constipation in advanced illness. N Engl J Med 2008;358:2332-43.

85. Wong BS, Rao AS, Camilleri M, et al. The effects of methylnaltrexone alone and in combination with acutely 
administered codeine on gastrointestinal and colonic transit in health. Aliment Pharmacol Ther 2010;32:884-93.

86. Webster LR, Brewer R, Wang C, et al. Long-term safety and efficacy of morphine sulfate and naltrexone hydrochloride extended release capsules, a novel formulation containing morphine and sequestered naltrexone, in patients with chronic, moderate to severe pain. J Pain Symptom Manage 2010;40:734-46.

87. Webster L, Jansen JP, Peppin J, et al. Alvimopan, a peripherally acting mu-opioid receptor (PAM-OR) antagonist for the treatment of opioid-induced bowel dysfunction: Results from a randomized, double-blind, placebo-controlled, dose-finding study in subjects taking opioids for chronic non-cancer pain. Pain 2008;137:428-40.

88. Gonenne J, Camilleri M, Ferber I, et al. Effect of alvimopan and codeine on gastrointestinal transit: A randomized controlled study. Clin Gastroenterol Hepatol 2005;3:784-91.

89. Neumann TA, van Paaschen H, Marcantonio A, et al. Clinical investigation of oral NKTR-118 as a selective oral peripheral opioid antagonist (Abst 27). Proceedings of the 18th Annual Clinical Meeting of the American Academy of Pain Management. Las Vegas, September 27 to 30, 2007.

90. Webster L, et al. Efficacy, safety and pharmacokinetices of oral NKTR-118 in patients with opiod-induced constipation: Results of a randomized, double-blind, placebo-controlled phase 2 study. Am J Gastroenterol 2009;104:S174.
91. Theravance. <http://files.shareholder.com/downloads/THERA/1065 $777793 \times 0 \times 411486 / 56 f c 683 c-c 436-4 a 24-85 d e-08622 a 292435 /$ THRX_1021.pdf $>$ (Accessed on June 27, 2011).

92. Bee LA, Bannister K, Rahman W, Dickenson AH. Mu-opioid and noradrenergic $\alpha(2)$-adrenoceptor contributions to the effects of tapentadol on spinal electrophysiological measures of nociception in nerve-injured rats. Pain 2011;152:131-9.

93. Afilalo M, Etropolski MS, Kuperwasser B, et al. Efficacy and safety of tapentadol extended release compared with oxycodone controlled release for the management of moderate to severe chronic pain related to osteoarthritis of the knee: Results of a randomized, double-blind, placebo- and active-controlled phase 3 study. Clin Drug Invest 2010;30:489-505.

94. Buynak R, Shapiro DY, Okamoto A, et al. Efficacy and safety of tapentadol extended release for the management of chronic low back pain: Results of a prospective, randomized, double-blind, placebo- and active-controlled phase III study. Expert Opin Pharmacother 2010;11:1787-804.

95. Slappendel R, Simpson K, Dubois D, et al. Development of the PAC-SYM questionnaire for opioid-induced constipation in patients with chronic low back pain. Eur J Pain 2006;10:209-17.

96. Sloots CE, Rykx A, Cools M, et al. Efficacy and safety of prucalopride in patients with chronic noncancer pain suffering from opioid-induced constipation. Dig Dis Sci 2010;55:2912-21. 


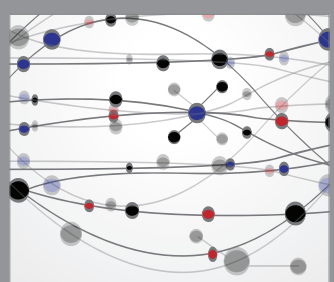

The Scientific World Journal
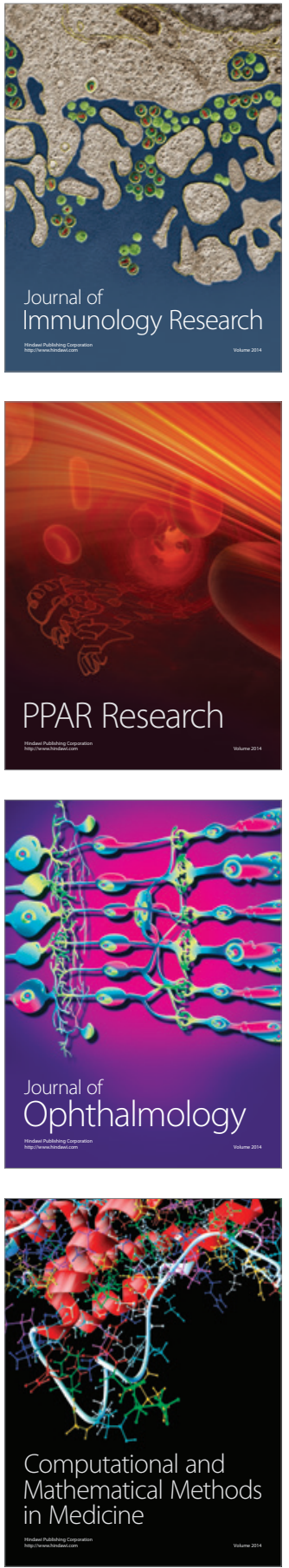

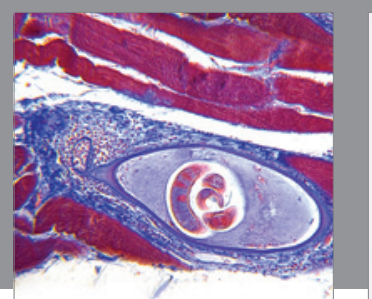

Gastroenterology Research and Practice

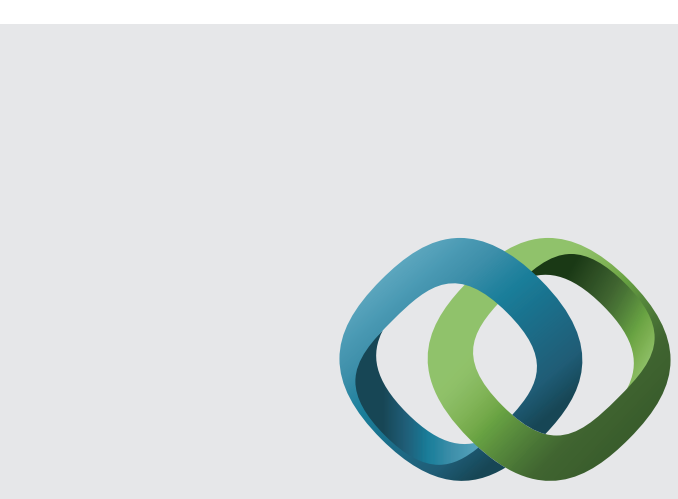

\section{Hindawi}

Submit your manuscripts at

http://www.hindawi.com
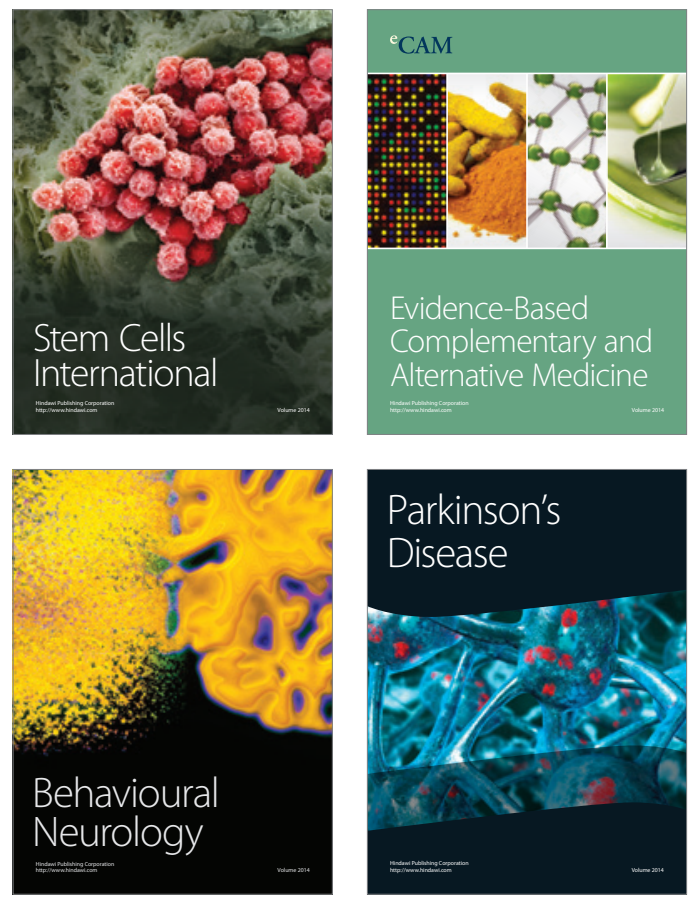
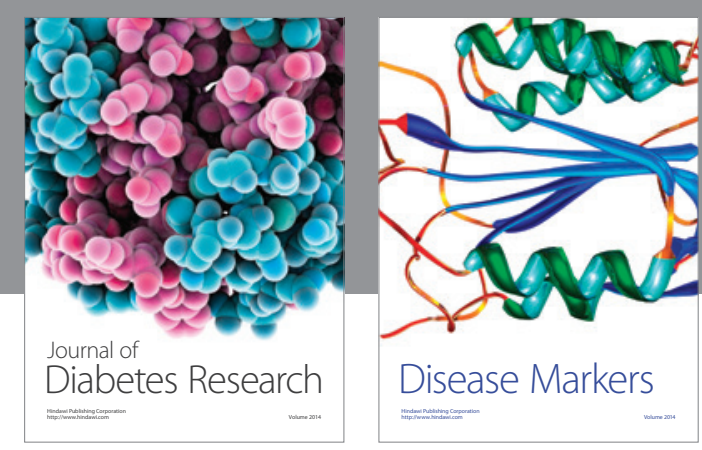

Disease Markers
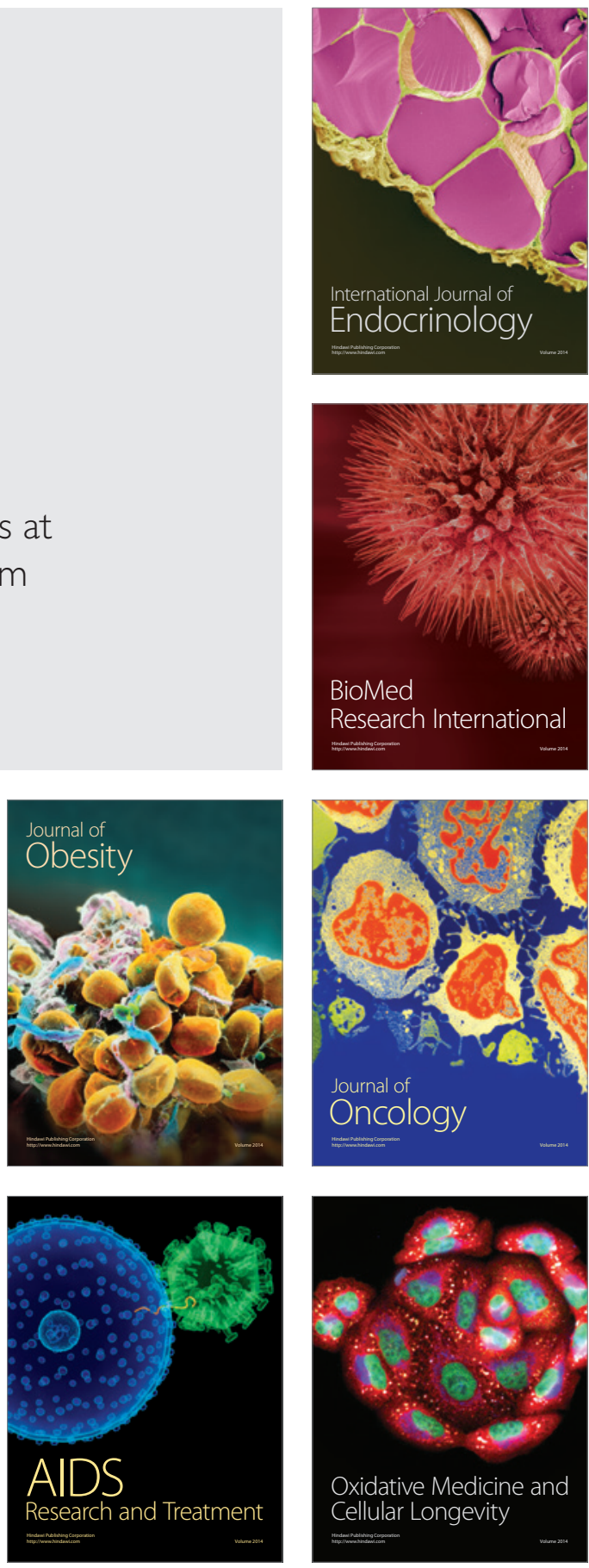